\section{Evaluation of Milkweed Floss as an Insulative Fill Material $^{*}$}

\author{
Patricia Cox Crews, Shiela A. Sievert, and Lisa T. Woeppel \\ Department of Textiles, Clothing and Design, \\ University of Nebraska, Lincoln, Nebraska 68583
}

Elizabeth A. McCullough

Institute for Environmental Research, Kansas State University, Manhattan, Kansas 66506

\begin{abstract}
Milkweed, a perennial plant that can adapt to adverse soil conditions, is being developed as an alternative crop. Fiber characterization and potential market identification are critical to its development. The most promising commercial use for milkweed floss is as a loose fill for jackets and comforters. The purpose of this research was to evaluate milkweed floss as an insulative fill material and to compare its performance to other insulators. Seven identical jackets were constructed using different fill materials matched on a per unit weight basis. The insulation (clo) values for the jackets were measured using a standing, heated manikin in an environmental chamber. Thickness (loft), compression, resiliency, and hand were also measured. Several performance characteristics were evaluated before and after cleaning. The results show that milkweed floss blended with down has insulative properties similar to down. Down is superior to milkweed floss in loftiness and compressibility, which influence product performance, but the properties of milkweed floss can be enhanced by blending with down.
\end{abstract}

Throughout most of the twentieth century, milkweed has been regarded as a stubborn weed with limited, if any, commercial value. However, scientists and farmers in the Midwest and elsewhere currently are re-

* Published in Textile Research Journal 61, no.4 (April 1991), pp. 203-210.

Copyright (C) 1991 Sage Publications. evaluating this widely held opinion and are actively investigating milkweed's potential as an alternative crop [1] and novel textile product [12]. Characterizing the fiber and identifying potential markets are critical to its development as an alternative crop. One of the most promising commercial uses for milkweed floss is as a loose fill material for jackets and comforters.

Milkweed belongs to the genus Asclepias, with over 80 distinct species of which 45 are indigenous to the United States. It is found in almost every state in the U.S. because it can adapt to almost any soil conditions from swampy and moist to sandy and arid. It is a perennial plant, and so, once planted does not require replanting each season. This contributes to its appeal as an alternative crop because, theoretically, it should be easy and economical to cultivate.

Asclepias syriaca, known as common milkweed, and Asclepias incarnata, commonly called swampweed, produce the best and most abundant floss $[6,13]$. However, Asclepias speciosa, often referred to as showy milkweed, is best adapted to the western Great Plains [ 1 ]. Both A. syriaca and A. speciosa are currently cultivated in Nebraska, and we evaluated a blend of these in this study. Our purpose was to evaluate milkweed floss as an insulative fill material and to compare its performance to other fill materials in terms of stiffness and hand, thickness and loft, compressibility and compressional recovery, and insulative properties.

\section{Materials and Methods}

Seven identical jackets were constructed from Parsenn jacket kits (Frostline Co., Grand Junction, CO). The outer fabric was a tightly woven poplin $\left(198 \mathrm{~g} / \mathrm{m}^{2}\right)$ of $83 \%$ polyester and $17 \%$ cotton; the lining was $100 \%$ nylon taffeta $\left(68 \mathrm{~g} / \mathrm{m}^{2}\right)$. Five of the jackets were constructed with different fill materials matched on a per unit weight basis. The loose fill materials included $100 \%$ milkweed floss (MW), 100\% down (D), 50\% milkweed floss $/ 50 \%$ down (MW/D), 50\% milkweed floss $/ 50 \%$ waterfowl feathers (MW/F), and 100\% Quallofil ${ }^{\circledR}$ polyester $(\mathrm{Q})$.

The milkweed was grown and processed in Utah and supplied by Natural Fibers Corporation (Ogallala, NE). The goose down was supplied by Frostline company with their jacket kits. The feathers were se- 
cured from a pillow purchased locally; the contents were $95 \%$ waterfowl feathers and 5\% down. The Quallofil, a Dacron III polyester insulation, was supplied by Dupont.

Two of the jackets were constructed using nonwoven batts instead of loose fill. One batt was Thinsulate ${ }^{\circledR}$ CS 150 (T), and one was an experimentally produced meltblown nonwoven of $60 \%$ milkweed and $40 \%$ microdenier olefin (MW/O) supplied by Natural Fibers Corporation. The milkweed/olefin batt was manufactured to be similar to Thinsulate CS 150 on an insulative basis [11], but its thickness was quite variable and on average was thinner than Thinsulate.

In addition, channeled samples were constructed using the same fill materials evaluated in the jackets because the jacket thickness data were so variable due to design features. The channeled samples (50.8 X 50.8 $\mathrm{cm}$ ), each with four channels that were five inches wide, were constructed of a $50 \%$ cotton and $50 \%$ polyester plain weave fabric (208 $\mathrm{g} / \mathrm{m}^{2}$ ). The loose fill materials were matched on a per unit weight basis.

\section{CLEANING PROCEDURES}

Four of the jackets (MW, D, MW/D, MW/F) were dry cleaned five times in perchloroethylene solvent and finished according to standard commercial practices. We selected dry cleaning as the cleaning method for these jackets because an informal survey of local sporting goods dealers and textile and clothing professors showed that dry cleaning was the recommended procedure as well as the most often used practice for cleaning and refurbishment of down-filled jackets.

The remaining three jackets $(\mathrm{Q}, \mathrm{T}, \mathrm{MW} / \mathrm{O})$ and channeled samples were laundered according to procedures described in AATCC test method 143-1984, appearance of apparel and other textile end products after repeated home launderings [3]. Conditions were AATCC machine washing procedure IV, normal cycle, with a water temperature of $49^{\circ}$ $\pm 3^{\circ} \mathrm{C}$, and tumble drying on moderate heat until the fill material was dry. We selected laundering for these jackets because the olefin fiber in the milkweed/olefin batt is sensitive to dry cleaning solvents (shrinks) as shown in preliminary work at the University of Nebraska-Lincoln. In addition, the recommended care procedures for Quallofil and Thinsulate are home laundering and tumble drying.

\section{HAND EVALUATION}

Hand, defined as the impressions that arise when a fabric is touched, rubbed, or handled, is a complex property influenced by many physical properties of textiles including surface contour, stiffness, thickness, and surface friction, as well as cultural and psychological responses of the wearer [9]. While many variables contribute to this attribute, we considered only surface contour (roughness/smoothness), stiffness, and thickness in this study. Others [15] have shown that these three attributes significantly influence sensory perceptions of hand in fabrics.

Surface contour (divergence of the surface from planeness) was evaluated independently by four trained judges using a rating scale of one to five, with one designating a lumpy, rough surface and five a smooth surface. To provide a basis for comparison, the judges were instructed to examine by touch the surface contour of all the jackets before rating individual jackets. Hand evaluations were done after cleaning.

Stiffness, another component of hand, was evaluated according to ASTM D 1388-64, standard test method for stiffness of fabrics, using a drape-flex stiffness tester [5]. A $100 \%$ filament polyester lining fabric (plain weave) was cut and sewn to specimen size $(2.5 \times 15.2 \mathrm{~cm})$ and subsequently loosely filled with the different materials. The loose fills (MW, MW/D, D, Q) were matched on a per unit weight basis. We did not prepare stiffness specimens using the milkweed/feather blend because of the small size of the test specimens $(2.5 \mathrm{~cm} \times 15.2 \mathrm{~cm})$ and the relatively large size of the feathers $(2.5-3.8 \mathrm{~cm}$ wide, $5-7.6 \mathrm{~cm}$ long). The batts (T, MW/0) could not be compared to the loose fills using this test method because they could not be matched on a per unit weight basis to the loose fills. When constructed into specimens with the batt layers intact, the specimens were so rigid and their flexural rigidity values so high that comparisons to the loose fills were meaningless. We prepared four specimens for each of the fill materials with the exceptions described above.

We measured the length of overhang on each specimen before cleaning, and from it calculated the bending length $\mathrm{c}$ and flexural rigidity $\mathrm{G}$ according to the following equations:

$$
c=O / 2 \text {, }
$$

where $O=$ length of overhang in $\mathrm{cm}$, and 


$$
G=W c^{3}
$$

where $W=$ weight per unit area in $\mathrm{mg} / \mathrm{cm}^{2}$.

\section{THICKNESS AND COMPRESSION}

We measured thickness at representative locations on the jackets and channeled samples before and after five cleanings according to ASTM D 1777-74, standard method for measuring thickness of textile materials [3]. We used a Frazier compressometer with a 3-inch presser foot to measure thickness to the nearest 0.001 inch under increasing loads ranging from 0.01 to 0.35 psi. Because of the variability in jacket thickness data due to design features that placed more fill material in the front than the back, we will report only thickness data on the channeled samples.

Total compression was calculated as a measure of the compressibility of the various fill materials using the following equation;

$$
\text { Total compression (inches) }=T_{0.01}-T_{0.35} \text {, }
$$

where $T_{0.01}=$ thickness at $0.01 \mathrm{psi}$ and $T_{0.35}=$ thickness at $0.35 \mathrm{psi}$. Compression recovery was calculated as a measure of the resiliency of the various fill materials using the following equation;

$$
\text { Compression recovery }(\%)=T_{R} / T_{o} \times 100,
$$

where $T_{o}=$ original thickness at $0.01 \mathrm{psi}$ and $T_{R}=$ recovered thickness at $0.01 \mathrm{psi}$ (after compression at $0.35 \mathrm{psi}$ ).

\section{THERMAL INSULATION}

We used an electrically heated manikin in an environmental chamber to measure the insulation or clo values of the jackets constructed using the seven fill materials. The manikin, consisting of a black anodized copper skin formed to simulate the physical shape and size of a typical man, was instrumented with 16 skin temperature sensors and heated internally to approximate the skin temperature distribution of a human. A proportional temperature controller maintained the average skin temperature of the manikin at $33^{\circ}$ :t $0.5^{\circ} \mathrm{C}$. A variable transformer regulated power to the hands and feet so that the average temperature of the extremities was $29.4^{\circ} \pm 0.5^{\circ} \mathrm{C}$. When the system reached steady state, the average power used to heat the manikin during a 30 minute test period was measured using a watt-hour meter.

Inside the climate-controlled chamber, the manikin was placed in a standing position and dressed in a standard clothing ensemble consisting of cotton underwear briefs, athletic socks, corduroy trousers, a longsleeved oxford shirt, knit gloves, and a knit hat. The jackets were stored hanging on a rack in the chamber so that they would be "conditioned" in the test environment. A jacket was placed over the standard ensemble for each test.

The air temperature in the chamber was measured using four thermistors placed on a stick positioned vertically about $0.3 \mathrm{~m}$ from the manikin and controlled at $15^{\circ} \pm 0.5^{\circ} \mathrm{C}$. The air velocity was maintained at $0.15 \mathrm{~m} / \mathrm{s}$ or essentially still air conditions. Relative humidity was not controlled at a specific level, but was held constant during each test.

The total insulation value (IT) of the clothing system plus the surrounding air layer was calculated using the following equation:

$$
I_{T}=\frac{K A_{s}\left(T_{\mathrm{s}}-T_{\mathrm{a}}\right)}{H},
$$

where $I_{T}=$ total thermal insulation of clothing plus the air layer in clo, $K$ $=$ constant $=6.45 \mathrm{clo} \mathrm{W} / \mathrm{m}^{2}{ }^{\circ} \mathrm{C}, T_{\mathrm{s}}=$ mean skin temperature in ${ }^{\circ} \mathrm{C}, T_{\mathrm{a}}=$ ambient air temperature in ${ }^{\circ} \mathrm{C}, A_{s}=$ manikin surface area in $\mathrm{m} 2$, and $H=$ power input in $\mathrm{W}$. Three independent replications of the test procedure were conducted on different days.

\section{STATISTICAL ANALYSIS}

Data obtained from surface contour ratings, stiffness, thickness, total compression, compressional recovery, and insulation values were analyzed statistically using an analysis of variance, Duncan's multiple range tests were used to determine where significant differences in surface contour, stiffness, thickness, total compression, and compressional recovery existed between the fill materials, Fisher's LSD post hoc comparison tests were used to determine where significant differences in insulation values existed for the fill materials used in the jackets. In addition, paired comparisons or t-tests were conducted to compare the vari- 
ous properties of the fill materials before and after cleaning. The level of significance was set at 0.05 for all tests.

\section{Results and Discussion}

\section{HAND EVALUATION}

The results of the analysis of variance performed on the surface contour data after cleaning showed that fill material type significantly affected the hand of the jackets $(F=28.98, p<0.001)$. The results of Duncan's multiple range tests in Table I indicate where significant differences in hand existed due to fill material. Surface contour ranged from a high of 4.8 (smooth) for the batt of $60 \%$ milkweed $/ 40 \%$ olefin to 1.0 (lumpy) for $100 \%$ milkweed floss. The jacket filled with $100 \%$ milkweed floss was perceived as significantly rougher or lumpier than the other jackets. Blending milkweed floss with down or feathers improved the hand (surface contour ratings); nevertheless, the $100 \%$ down jacket was rated as significantly smoother than any of the jackets constructed with the milkweed fills after cleaning.

Table I.

Duncan's tests for the effects of fill material on surface contour after cleaning.

\begin{tabular}{lll} 
Fill type & $\begin{array}{l}\text { Surface } \\
\text { contour, } \\
\text { rating }^{\mathrm{a}}\end{array}$ & $\begin{array}{l}\text { Duncan's } \\
\text { grouping }^{\mathrm{b}}\end{array}$ \\
\hline
\end{tabular}

\section{After cleaning}

$\begin{array}{lll}60 \% \text { Milkweed } / 40 \% \text { olefin } & 4.8 & \mathrm{~A} \\ 100 \% \text { Thinsulate } & 4.6 & \mathrm{~A} \\ 100 \% \text { Down } & 4.6 & \mathrm{~A} \\ 100 \% \text { Quallofil } & 3.8 & \mathrm{~B} \\ 50 \% \text { Milkweed } / 50 \% \text { down } & 2.6 & \mathrm{C} \\ 50 \% \text { Milkweed } / 50 \% \text { feathers } & 2.6 & \mathrm{C} \\ 100 \% \text { Milkweed } & 1.0 & \mathrm{D}\end{array}$

$\bar{a}$ Rating of $5=$ smooth; $1=$ rough. ${ }^{b}$ Means with the same letter designation were not significantly different at the 0.05 level.
Stiffness properties are an important consideration for insulation materials used in clothing and textile products because an excellent thermal insulator is of little use if it is not flexible enough to allow the wearer mobility and comfort. Results from the analysis of variance on stiffness data showed that fill type was a significant independent variable $(\mathrm{F}=677.27, p<0.001)$. The flexural rigidity for the fill materials ranged from 2828.9 for Quallofil to 1019.3 for the $100 \%$ milkweed as shown in Table II. The milkweed/down blend had a higher flexural rigidity than either the down or milkweed alone. The reason for this result is unclear.

Table II.

Duncan's test for the effect of fill type on stiffness.

\begin{tabular}{lcc} 
Fill type & $\begin{array}{c}\text { Flexural } \\
\text { rigidity, } \\
\text { mg-cm }\end{array}$ & $\begin{array}{c}\text { Duncan's } \\
\text { grouping }^{\text {a }}\end{array}$ \\
\hline 100\% Quallofil & 2828.9 & $\mathrm{~A}$ \\
$50 \%$ Milkweed/50\% down & 1469.2 & $\mathrm{~B}$ \\
100\% Milkweed & 1032.2 & $\mathrm{~B}$ \\
100\% Down & 1019.3 & $\mathrm{~B}$ \\
Fabric covering & 352.6 & $\mathrm{C}$ \\
\hline
\end{tabular}

${ }^{a}$ Means with the same letter designation were not significantly different at the 0.05 level.

The results of Duncan's multiple range test on mean flexural rigidity showed that the loose fills of milkweed and down (MW, D, MW/D) were the softest, most flexible fill materials. The flexural rigidity of Quallofil was about twice as high as the other loose fills. This may be attributed to the size of the polyester fibers, which were larger in diameter than the very fine milkweed fibers.

\section{THICKNESS}

The thicknesses of the jackets and channeled samples were measured under 0.01 and $0.35 \mathrm{psi}$ of pressure, and from these measurements total compression and compressional recovery were calculated. The variability in thickness data due to jacket design masked existing variations, and so 
we will discuss only thickness data for the channeled samples. The thickness measurements for the channeled samples ranged from 1.048 in. for the Quallofil to $0.251 \mathrm{in}$. for the milkweed/olefin batt before cleaning, and from $0.938 \mathrm{in}$. for the Quallofil $\sim 0.221 \mathrm{in}$. for the milkweed/olefin batt after cleaning as shown in Table III. The analysis of variance on the thickness of the channeled samples showed that there were significant differences between fill types before cleaning $(F=49.81, p<0.0001)$ and after five cleanings $(F=62.00, p<0.0001)$. The results of Duncan's test (Table 111) showed that Quallofil and down were significantly thicker and therefore loftier fill materials than milkweed or milkweed blends, because all samples were matched on a per unit weight basis except the battings of Thinsulate and milkweed/olefin.

Table III.

Duncan's test for the effect of fill material on thickness before and after cleaning.

\begin{tabular}{lcc} 
Fill type & $\begin{array}{c}\text { Thickness, } \\
\text { inches }\end{array}$ & $\begin{array}{c}\text { Duncan's } \\
\text { grouping }^{\text {a }}\end{array}$ \\
\hline Before cleaning & 1.048 & \\
$\quad$ 100\% Quallofil & 1.010 & $\mathrm{~A}$ \\
100\% Down & 0.876 & $\mathrm{~A}$ \\
50\% Milkweed $/ 50 \%$ feathers & $\mathrm{B}$ \\
50\% Milkweed/50\% down & 0.834 & $\mathrm{~B}$ \\
100\% Milkweed & 0.824 & $\mathrm{~B}$ \\
100\% Thinsulate & 0.428 & $\mathrm{C}$ \\
60\% Milkweed/40\% olefin & 0.251 & $\mathrm{D}$ \\
After cleaning & & \\
100\% Quallofil & 0.938 & $\mathrm{~A}$ \\
100\% Down & 0.911 & $\mathrm{~A}$ \\
$50 \%$ Milkweed $/ 50 \%$ feathers & 0.721 & $\mathrm{~B}$ \\
50\% Milkweed/50\% down & 0.667 & $\mathrm{~B}$ \\
100\% Milkweed & 0.693 & $\mathrm{~B}$ \\
100\% Thinsulate & 0.405 & $\mathrm{C}$ \\
$60 \%$ Milkweed/40\% olefin & 0.221 & $\mathrm{D}$ \\
\hline
\end{tabular}

${ }^{\mathrm{a}}$ Means with the same letter designation were not significantly different at the 0.05 level.
Thickness is an important property to measure because it significantly influences the insulative properties of fill materials. A material's thermal insulation properties are generally proportional to its thickness $[8,10,14]$. These data show that down and Quallofil should provide the thickest jackets and comforters if equal amounts of fill material (weight basis) are used in constructing the items.

Paired comparisons performed on the thickness data of the channeled samples before and after cleaning (see Table IV) show that cleaning significantly affected the thickness of Quallofil and the loose fills containing milkweed (MW, MW ID and MW IF). The thickness of the other fills (D, T, MW 10) was not significantly affected by cleaning. Clearly, cleaning significantly decreased the thickness of the loose fills containing milkweed and thus would likely decrease their insulation properties.

Table IV.

Paired comparisons of thickness for each fill material before and after cleaning.

\begin{tabular}{|c|c|c|c|}
\hline \multirow[t]{2}{*}{ Fill type } & \multicolumn{2}{|c|}{$\begin{array}{c}\text { Mean thickness, } \\
\text { inches }\end{array}$} & \multirow{2}{*}{$\begin{array}{c}\begin{array}{c}\text { Level of } \\
\text { significance }\end{array} \\
0.070\end{array}$} \\
\hline & before & 1.01 & \\
\hline \multirow[t]{2}{*}{$100 \%$ Down } & after & 0.911 & \\
\hline & before & 0.824 & 0.017 \\
\hline \multirow[t]{2}{*}{ 100\% Milkweed } & after & 0.693 & \\
\hline & before & 0.834 & 0.003 \\
\hline \multirow{2}{*}{$50 \%$ Milkweed $/ 50 \%$ down } & after & 0.667 & \\
\hline & before & 0.876 & 0.005 \\
\hline \multirow[t]{2}{*}{$50 \%$ Milkweed $/ 50 \%$ feathers } & after & 0.721 & \\
\hline & before & 1.048 & 0.045 \\
\hline \multirow[t]{2}{*}{ 100\% Quallofil } & after & 0.938 & \\
\hline & before & 0.428 & 0.671 \\
\hline \multirow[t]{2}{*}{$100 \%$ Thinsulate } & after & 0.405 & \\
\hline & before & 0.251 & 0.576 \\
\hline $60 \%$ Milkweed $/ 40 \%$ olefin & after & 0.221 & \\
\hline
\end{tabular}




\section{COMPRESSION}

Total compression was calculated as an indicator of compressibility of the fill materials. Compressible fills conform better to the shape of the body and in that way keep the wearer warmer. The analysis of variance for the total compression of the fill materials in the jackets showed that fill type was a significant independent variable before $(F=97.50, p<$ $0.0001)$ and after $(F=108.81, p<0.0001)$ cleaning. Duncan's test performed on the data (see Table V) showed that the down and the Quallofil were significantly more compressible than the other materials. When down or feathers were blended with milkweed floss, the compressibility of the floss significantly improved. The $100 \%$ milkweed floss was the least compressible of the loose fill materials.

Table V.

Duncan's test for the effect of fill material on total compression before and after cleaning

\begin{tabular}{lll} 
Fill type & $\begin{array}{c}\text { Compression, } \\
\text { inches }\end{array}$ & $\begin{array}{c}\text { Duncan's } \\
\text { grouping }\end{array}$ \\
\hline Before cleaning & 0.927 & $\mathrm{~A}$ \\
100\% Quallofil & 0.834 & $\mathrm{~B}$ \\
100\% Down & 0.690 & $\mathrm{C}$ \\
$50 \%$ Milkweed $/ 50 \%$ feathers & 0.620 & $\mathrm{C}$ \\
50\% Milkweed $/ 50 \%$ down & 0.518 & $\mathrm{D}$ \\
100\% Milkweed & 0.315 & $\mathrm{E}$ \\
100\% Thinsulate & 0.156 & $\mathrm{~F}$ \\
60\% Milkweed $/ 40 \%$ olefin & & \\
After cleaning & 0.793 & $\mathrm{~A}$ \\
100\% Quallofil & 0.792 & $\mathrm{~A}$ \\
100\% Down & 0.524 & $\mathrm{~B}$ \\
$50 \%$ Milkweed $/ 50 \%$ feathers & 0.435 & $\mathrm{C}$ \\
$50 \%$ Milkweed $/ 50 \%$ down & 0.405 & $\mathrm{C}$ \\
100\% Milkweed & 0.299 & $\mathrm{D}$ \\
100\% Thinsulate & 0.138 & $\mathrm{E}$ \\
$60 \%$ Milkweed $/ 40 \%$ olefin &
\end{tabular}

${ }^{\mathrm{a}}$ Means with the same letter designation were not significantly different at the 0.05 level.
Comparisons of total compression of the channeled samples before and after cleaning for each fill type are shown in Table VI. The results show that cleaning significantly affected the compressibility of the milkweed fills as well as Quallofil, but not the down and the two batt materials (T, MW 10).

Table VI.

Paired comparisons of total compression for each fill material before and after cleaning.

\begin{tabular}{|c|c|c|c|}
\hline Fill type & \multicolumn{2}{|c|}{ Compression, inches } & $\begin{array}{c}\text { Level of } \\
\text { significance }\end{array}$ \\
\hline \multirow[t]{2}{*}{$100 \%$ Down } & before & 0.834 & 0.254 \\
\hline & after & 0.792 & \\
\hline \multirow[t]{2}{*}{ 100\% Milkweed } & before & 0.513 & 0.003 \\
\hline & after & 0.340 & \\
\hline \multirow[t]{2}{*}{$50 \%$ Milkweed $/ 50 \%$ feathers } & before & 0.690 & 0.000 \\
\hline & after & 0.524 & \\
\hline \multirow[t]{2}{*}{$50 \%$ Milkweed/SO $\%$ down } & before & 0.620 & 0.000 \\
\hline & after & 0.435 & \\
\hline \multirow[t]{2}{*}{ 100\% Quallofill } & before & 0.927 & 0.000 \\
\hline & after & 0.793 & \\
\hline \multirow[t]{2}{*}{$100 \%$ Thinsulate } & before & 0.315 & 0.681 \\
\hline & after & 0.299 & \\
\hline \multirow[t]{2}{*}{$60 \%$ Milkweed $/ 40 \%$ olefin } & before & 0.156 & 0.623 \\
\hline & after & 0.138 & \\
\hline
\end{tabular}

The analysis of variance performed on the mean compressional recovery for the channeled samples showed that fill type was a significant independent variable both before $(F=5.74, p<0.0003)$ and after $(F=$ $11.28, p<0.0001)$ cleaning. The compressional recovery ranged from a high of $73 \%$ for the Thinsulate to a low of $58 \%$ for the milkweed/feathers before cleaning, and from $72 \%$ for the Thinsulate to $54 \%$ for the down after cleaning (see Table VII). 
Table VII.

Duncan's test for the effect of fill material on compression recovery before and after cleaning.

\begin{tabular}{|c|c|c|c|}
\hline \multirow{2}{*}{$\frac{\text { Fill type }}{\text { Before cleaning }}$} & \multirow[t]{2}{*}{$\%$ Recovery } & \multicolumn{2}{|c|}{$\begin{array}{l}\text { Duncan's } \\
\text { grouping }^{\mathrm{a}}\end{array}$} \\
\hline & & & \\
\hline $100 \%$ Thinsulate & 73 & A & \\
\hline 100\% Milkweed & 69 & A & \\
\hline 100\% Quallofil & 68 & A B & \\
\hline $60 \%$ Milkweed $/ 40 \%$ olefin & 67 & A B & \\
\hline $50 \%$ Milkweed $/ 50 \%$ down & 62 & B & $\mathrm{C}$ \\
\hline 100\% Down & 59 & & $\mathrm{C}$ \\
\hline $50 \%$ Milkweed $/ 50 \%$ feathers & 58 & & $\mathrm{C}$ \\
\hline \multicolumn{4}{|l|}{ After cleaning } \\
\hline $100 \%$ Thinsulate & 72 & A & \\
\hline 100\% Milkweed & 69 & A B & \\
\hline 100\% Quallofil & 65 & B & $\mathrm{C}$ \\
\hline $60 \%$ Milkweed $/ 40 \%$ olefin & 65 & B & $\mathrm{C}$ \\
\hline $50 \%$ Milkweed $/ 50 \%$ down & 64 & $\mathrm{~B}$ & $\mathrm{C}$ \\
\hline $50 \%$ Milkweed $/ 50 \%$ feathers & 61 & & $\mathrm{C}$ \\
\hline $100 \%$ Down & 54 & & $\mathrm{D}$ \\
\hline
\end{tabular}

${ }^{\mathrm{a}}$ Means with the same letter designation were not significantly different at the 0.05 level.

Surprisingly, down had the lowest compressional recovery of all the fill materials after cleaning, a finding that does not support most previous research. Albany International Research Company [2] conducted compressional recovery tests on both down and milkweed floss and found an $80 / 20$ down/feather mixture to have a compressional recovery value of $102 \%$, while a milkweed sample had a compressional recovery value of $72 \%$. The compressometer method used for evaluating compressional recovery in this research had a very brief recovery time (less than 10 seconds) and no mechanical fluffing of the material, in contrast with a five minute recovery time in the method used by Albany International, which was an adaptation of military specification MIL-B-41826E for fibrous insulating batting [2]. Under these conditions, down had the low- est recovery; in actual use, it may not. Longer recovery times or other methods for measuring compressional recovery are recommended for more meaningful data when evaluating these materials. Paired comparisons of percent compressional recovery of the channeled samples before and after cleaning show that cleaning did not significantly affect the compressional recovery of the different fill materials.

Table VIII.

LSD tests on insulative value for filling material type before and after cleaning.

\begin{tabular}{lcc} 
Fill type & $\begin{array}{c}\text { Insulation value } \\
I_{T} \text {, clo }\end{array}$ & $\begin{array}{c}\text { LSD } \\
\text { grouping }^{\mathrm{a}}\end{array}$ \\
\hline Before cleaning & & \\
50\% Milkweed floss/50\% down & 2.36 & $\mathrm{~A}$ \\
100\% Down & 2.28 & $\mathrm{~B}$ \\
100\% Quallofil & 2.26 & $\mathrm{~B}$ \\
100\% Milkweed & 2.24 & $\mathrm{~B}$ \\
50\% Milkweed/50\% feathers & 2.24 & $\mathrm{~B}$ \\
100\% Thinsulate & 2.15 & $\mathrm{C}$ \\
60\% Milkweed/40\% olefin & 2.04 & $\mathrm{D}$ \\
After cleaning & & \\
100\% Down & 2.26 & $\mathrm{~A}$ \\
$50 \%$ Milkweed floss/50\% down & 2.25 & $\mathrm{~A}$ \\
100\% Quallofil & 2.19 & $\mathrm{~B}$ \\
$50 \%$ Milkweed $/ 50 \%$ feathers & 2.16 & $\mathrm{~B}$ \\
100\% Thinsulate & 2.06 & $\mathrm{C}$ \\
100\% Milkweed & 2.04 & $\mathrm{C}$ \\
$60 \%$ Milkweed/40\% olefin & 1.97 & $\mathrm{D}$ \\
\hline
\end{tabular}

${ }^{\mathrm{a}}$ Means with the same letter designation were not significantly different at the 0.05 level. 


\section{THERMAL INSULATION VALUES}

The analysis of variance results showed that the fill materials used in the jackets significantly affected thermal insulation values before $(F=29.12$, $\mathrm{p}<0.0 \mathrm{I})$ and after $(\mathrm{F}=57.84, \mathrm{p}<0.01)$ cleaning. The insulation values ranged from 2.04 clo for the milkweed/olefin jacket to 2.36 clo for the $50 \%$ milkweed floss $/ 50 \%$ down jacket prior to cleaning (see Table VIII). The range of clo values after cleaning was from 1.97 for the milkweed/olefin jacket to 2.26 and 2.25 for the $100 \%$ down and the $50 \%$ milkweed floss $/ 50 \%$ down jackets, respectively. Because of the precision of the manikin instrumentation, differences smaller than 0.1 clo between jackets were statistically significant, but these differences cannot be perceived by most people. A 0.1 change in clo value is equivalent to about a $0.6^{\circ} \mathrm{C}\left(1^{\circ} \mathrm{F}\right)$ change in preferred temperature for sedentary people in comfortable environments [4]. As the temperature drops, comfort depends more on the maintenance of a reasonably uniform distribution of clothing insulation over the entire body, and more insulation is needed for an equivalent temperature change. Depending on the environmental conditions, people may not be able to perceive a difference in warmth or comfort between the jackets tested in this study except for the jackets with the extremely high and low insulation values. The milkweed jacket that has the highest insulation value both before and after cleaning is the one filled with the $50 \%$ milkweed floss $/ 50 \%$ down mixture.

To determine which jackets had lower insulation values after cleaning, we conducted paired t-tests, and the results are given in Table IX. Most of the jackets lost about 0.1 clo of insulation due to cleaning; the $100 \%$ down jacket was the only one that did not have a significant insulation loss. In addition, the $100 \%$ milkweed floss lost more insulation than the others (i.e.. $0.2 \mathrm{clo}$ ) due to cleaning.
Table IX.

Paired $t$-tests on insulation values for each fill material before and after cleaning.

\begin{tabular}{|c|c|c|c|}
\hline Fill type & $\begin{array}{l}\text { Insulati } \\
\qquad I_{T}\end{array}$ & $I_{T}$, clo & $t$ value $^{\mathrm{a}}$ \\
\hline \multirow[t]{2}{*}{$50 \%$ Milkweed $/ 50 \%$ down } & before & 2.36 & $3.75 *$ \\
\hline & after & 2.25 & \\
\hline \multirow[t]{2}{*}{ 100\% Quallofil } & before & 2.26 & $3.66^{*}$ \\
\hline & after & 2.19 & \\
\hline \multirow[t]{2}{*}{$50 \%$ Milkweed floss $/ 50 \%$ feathers } & before & 2.24 & $2.88 *$ \\
\hline & after & 2.16 & \\
\hline \multirow[t]{2}{*}{ 100\% Thinsulate } & before & 2.15 & $4.43 * *$ \\
\hline & after & 2.06 & \\
\hline \multirow[t]{2}{*}{$60 \%$ Milkweed $/ 40 \%$ olefin } & before & 2.04 & $3.05 *$ \\
\hline & after & 1.97 & \\
\hline \multirow[t]{2}{*}{ 100\% Down } & before & 2.28 & 1.25 \\
\hline & after & 2.26 & \\
\hline \multirow[t]{2}{*}{ 100\% Milkweed } & before & 2.24 & $7.28 * *$ \\
\hline & after & 2.04 & \\
\hline
\end{tabular}

a "Significantly different at the 0.05 level, ${ }^{* *}$ significantly different at the 0.01 level.

\section{Conclusions}

The $100 \%$ milkweed did not perform satisfactorily as a loose fill material. It was rated significantly rougher and lumpier than any other fill material, was significantly thinner (less lofty) than $100 \%$ down (although matched on a per unit weight basis), was the least compressible of the loose fill materials, and had the lowest insulation value of the loose fills. Furthermore, cleaning significantly affected the $100 \%$ milkweed fill; it became very matted and lumpy after cleaning, decreasing significantly in thickness, compressibility, and insulation value. The decreased thickness after cleaning corresponds with its considerable decrease in insulative 
value after cleaning. Therefore, we cannot recommend $100 \%$ milkweed as a loose fill material.

When milkweed was blended with down or feathers, its performance properties were enhanced. The insulative value of the blend of $50 \%$ milkweed $/ 50 \%$ down was very similar to the $100 \%$ down product. The blend had a clo value significantly higher than down before cleaning and similar to down after cleaning. The compressibility values of milkweed/down and milkweed/feathers were significantly higher than $100 \%$ milkweed before cleaning, although both were lower than $100 \%$ down. Blending down or feathers with milkweed also improved the hand of the blended materials: both blends were perceived as significantly smoother than the $100 \%$ milkweed.

The thin milkweed batt material consisting of $60 \%$ milkweed and $40 \%$ olefin performed comparably to Thinsulate in maintaining its smooth hand during cleaning unlike the loose fill material of $100 \%$ milkweed. Although the milkweed/olefin batt was much thinner than the Thinsulate $(\mathrm{MW} / \mathrm{O}=0.2 \mathrm{in}$. versus $\mathrm{T}=0.4 \mathrm{in}$.), the clo values of the two batts were remarkably similar $(\mathrm{MW} / \mathrm{O}=1.97$ versus $\mathrm{T}=2.04)$. While they were significantly different statistically, it is doubtful that Thinsulate would be perceptibly warmer to humans.

Based on the results of this research, down or feathers should be blended with milkweed floss when used as an insulative fill material. Down is particularly useful in optimizing the performance properties of milkweed floss, and milkweed does not decrease the insulative properties of down. It appears that the major incentive for down jacket and comforter producers to blend milkweed with down would be for economic reasons and not to improve the performance properties of down. Currently, milkweed is marketed for about one-half the price of goose down and, as production increases, the price of milkweed floss may be further reduced. This should make milkweed attractive to down producers who can use it to reduce costs.

\section{ACKNOWLEDGMENTS}

This research was supported by Nebraska Research and Development Authority, Lincoln; Natural Fibers Corporation, Ogallala, NE; a United States Department of Agriculture Special Grant; and the University of Nebraska Agricultural Research Division Journal series no.9254). We extend appreciation to Williams Cleaners, Lincoln, for so generously agreeing to dry clean the jackets.

\section{Literature Cited}

1. Adams, R. P., Balandrin, M. F., and Martineau, J. R., The Showy Milkweed, Asclepias Speciosa: A Potential New Semi-Arid Land Crop for Energy and Chemicals, Biomass 4,81-104 (1984).

2. Albany International Research Company, Preliminary Evaluation of Milkweed Fiber as a Thermal Insulator, Report for Standard Oil Company of Ohio, Case No. 37099, April 10, 1987.

3. American Association of Textile Chemists and Colorists, "AATCC Technical Manual," Research Triangle Park, NC, 1985.

4. American Society of Heating, Ventilating, and Air-Conditioning Engineers, Thermal Environmental Conditions for Human Occupancy, standard 55-1981, Atlanta, GA, 1981.

5. American Society for Testing and Materials, Committee D-13, "Annual Book of ASTM Standards," vol. 07.01, Philadelphia, PA, 1985.

6. Cook, G. J., "Handbook of Textile Fibres: 1. Natural Fibres," Merrow Publishing Co., Watford, England, 1968.

7. Gagge, A. P., Burton, A. C., Bazett,H. D., A Practical System of Units for the Description of Heat Exchange of Man with his Environment, Science 94, 428-430 (1941).

8. Hollies, N. R. S., and Goldman, R. F., Eds., "Clothing Comfort," Ann Arbor Science Publishers, Inc., Ann Arbor, MI, 1977.

9. Kaswell, E. R., "Textile Fibres, Yams and Fabrics," Reinhold, New York, 1953. 
10. Kaufman, W. C., Bothe, D. J., and Meyer, S. D., Thermal Insulating Capabilities of Outdoor Clothing Materials, Science 215, 690-691 (1982).

11. Knudsen, H. D., President, Natural Fibers Corporation, Ogallala, NE, personal communication, June, 1988.

12. Louis, a. L., and Andrews, B. A. K., Cotton/Milkweed Blends: A Novel Textile Product, Textile Res. J. 57,339-345 ( 1987).

13. Mauersberger, H. R., Ed., "Matthews' Textile Fibers," 6th ed., John Wiley and Sons, New York, 1954.

14. McCullough, E. A., and Rohles, F. H., Quantifying the Thermal Protection Characteristics of Outdoor Clothing Systems, Human Factors 25,191-198 (1983).

15. Winakor, G., Kim, C. J. and Wolin, K., Fabric Hand: Tactile Sensory Assessment, Textile Res. J. 50,601-610 (1980).

Manuscript received July 3. 1990; accepted September 11, 1990. 